and Russian abstracts) and Archives of Psychiatry and Psychotherapy (in English).

\section{Human rights issues}

From the late 1940s to the 1980s, as the Polish Psychiatric Association watching group noted (Bomba et al, 1993), there was no abuse of psychiatry for political reasons. Since 1994 the Mental Health Act has provided for the prevention of abuse of the right to personal freedom in psychiatric practice. Professionals are obliged to offer treatment, if needed, after obtaining informed consent. The major human rights issue remains deprivation of privacy in psychiatric wards due to chronic unsatisfactory funding (Buda et al, 1998).

\section{References}

Aleksandrowicz, J. (1991) Psychotherapiefgorschung in Polen. [Psychotherapy research in Poland.] In Psychoterapie in der Medizin [Psychotherapy in medicine] (ed. E. Brahler). Westd Verl.

Bomba, J. \& Cichocki, Ł. (2005) Czy neuroscience wyjasnia efekty psychoterapii schizofrenii? [Does neuroscience explain the effects of psychotherapy in schizophrenia?] Psychoterapia, 2, 5-11.

Bomba, J., Szymusik, A. \& Piotrowski, A. (1993) Psychiatry in Eastern Europe. American Journal of Psychiatry, 150, 988-989.
Buda, B., Gondios, A. \& Demetrovics, Z. (eds) (1998) Costs of Rights in Psychiatry. CLPI.

Cechnicki, A. (1998) Analiza wpływu wybranych czynników na wyniki leczenia w obszarze społecznym. Krakowskie prospektywne badania przebiegu schizofrenii. [Selected factors impact on social area results of schizophrenia treatment. The Krakow prospective follow-up study.] Badania Nad Schizofrenia, 1, 37-48.

Heitzman, J. \& Rutkowski, K. (2002) Mental disturbances in former political prisoners persecuted in Poland in the years 1944-1956. Dialog. Zeszyty Polsko-Niemieckiego Towarzystwa Zdrowia Psychicznego, Hefte dre Deutsch-Polnishen Gesellschaft fur Seeliche Gesundheit, 11, 206-211.

Institute of Psychiatry and Neurology (2006) Zakłady psychiatrycznej oraz neurologicznej opieki zdrowotnej. Rocznik statystyczny 2005. [Psychiatric and neurological health care services. Statistical yearly 2005.] Institute of Psychiatry and Neurology.

Józefik, B. \& Pilecki, M. (2004) Therapeutic implications of the individual, familial and cultural context of eating disorders in Poland. World Psychiatry, 3 (suppl. 1), 293.

Kepinski, A. (1970) The so-called 'KZ-syndrom' - an attempt at a synthesis. Przeglad Lekarski, 26, 18-23. Reprinted in Przeglad Lekarski, Krakow, 141-156 (ed. J. Z. Ryn, 2002).

Meder, J. \& Cechnicki, A. (2002) Rehabilitation of the mentally ill in Poland. In Images in Psychiatry. Poland (eds A. Bilikiewicz \& J. Rybakowski), pp. 142-157. WPA, PTP, Via Medica.

Orwid, M., Domagalska-Kurdziel, E., Kaminska, M., et al (2002) The Holocaust in Polish publications. In Images in Psychiatry. Poland (eds A. Bilikiewicz \& J. Rybakowski), pp. 83-114. WPA, PTP, Via Medica.

Zieba, A., Dudek, D. \& Jawor, M. (1997) Cognitive style in depressed patients over three-year follow-up. European Journal of Psychiatry, 11, 244-250.

\title{
Mental health in New Zealand
}

\section{A. P. McGeorge QSO FRANZCP}

Oceania Vice-President, World Federation for Mental Health, email peter.mcgeorge@gmail.com

N ew Zealand's healthcare system has undergone significant changes in recent times, among them being the establishment in 1993 of a purchaser/provider split and the specific attention given to the development of mental health services. Funding for mental health services (Fig. 1) increased from NZ\$270 million in 1993/94 to NZ\$866.6 million per annum in 2004/05, a real increase (adjusted for inflation) of $154 \%$ (Mental Health Commission, 2006). The bi-partisan political commitment sustaining this funding has had a major impact on the development of recoverybased and culturally specific models of care unrivalled by few countries in the world. However, recent reports (Mental Health Commission, 2006) indicate that, particularly with regard to access, much still remains to be done to address the mental health needs of New Zealanders.

New Zealand is a Pacific country of 4.15 million people. At the last census (2001), with three responses allowed per person, $80 \%$ identified themselves as being European, 15\% as being indigenous Maori, 6.5\% Pacific Island and 6.6\% Asian, with other ethnicities accounting for less than $1 \%$ of the population. These categories are very broad and only partially describe the situation that exists in New Zealand. For example, while $91 \%$ identified with one ethnicity, $44 \%$ of
Maori identified with multiple ethnicities (Ministry of Social Development, 2006).

The median age of the population is 36 years. The overall male/female gender ratio is 0.99 . The unemployment rate currently stands at around $4 \%$.

\section{Healthcare structure}

While there is a substantial private sector in medicine and particularly in surgery, the public and not-for-profit sectors dominate over the private sector in the delivery of mental health services. For example, less than $10 \%$ of psychiatrists in New Zealand work in the private sector.

The Ministry of Health oversees the development and delivery of health services. It implements government policy and is responsible for the regulation and statutory oversight of the Mental Health Act 1992.

Health services are funded by the Ministry via 21 district health boards, which are responsible for the health of defined populations and catchment areas. Each district health board, guided by the objectives of the Ministry of Health's $2000 \mathrm{New}$ Zealand Health Strategy and 2001 New Zealand Disability 


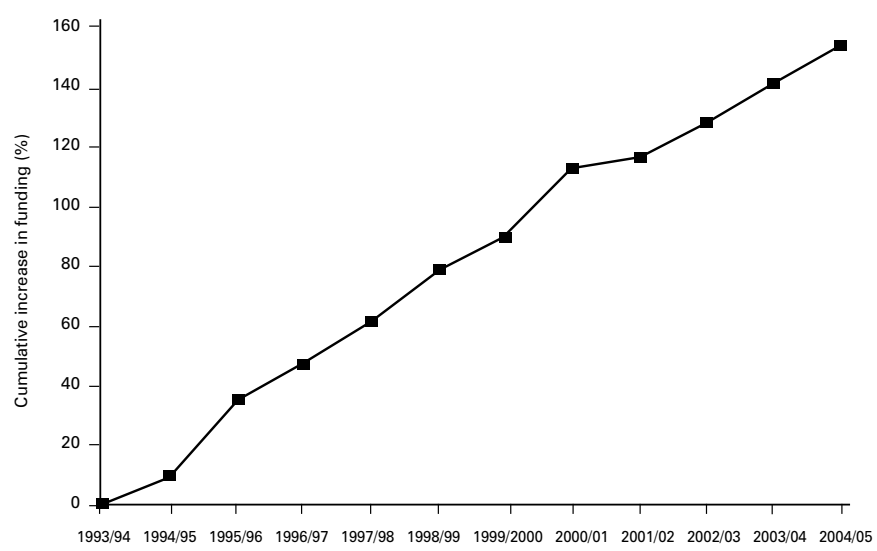

Fig. 1 Real cumulative percentage increase in public funding for mental health services in New Zealand, $1993 / 94$ (NZ\$270 million baseline) to 2004/05. Source: Mental Health Commission (2006).

Strategy, has a board comprising appointed and elected members that reports to the Minister of Health through the Ministry of Health. Specialist public services, non-governmental organisations (NGOs) and primary healthcare organisations are funded by the district health boards to provide a range of inpatient and community mental health services.

\section{Epidemiology}

The recently published New Zealand Mental Health Survey (Ministry of Health, 2006) indicated that mental disorder is common: $46.6 \%$ of the population were predicted to meet criteria for any mental disorder with the exception of psychoses (because the Composite International Diagnostic Interview - 3 instrument used does not generate diagnoses for such disorders) at some time in their lives, with $39.5 \%$ having already done so and $20.7 \%$ having a disorder in the past 12 months.

The prevalence of disorder in any period is higher for Maori and Pacific people than for other ethnic groups. For instance, the prevalence of disorder in the past 12 months is $29.5 \%$ for Maori, $24.4 \%$ for Pacific people and $19.3 \%$ for others. Much of this burden appears to be associated with the youthfulness of the Maori and Pacific populations and their relative socio-economic disadvantage.

Psychotic disorders have an estimated prevalence of approximately $0.3 \%$ of the population; however, in a study of in-patient units in Auckland, New Zealand's largest city, they accounted for around half of all acute psychiatric admissions, with schizophrenia being the most common diagnosis (Wheeler et al, 2005).

\section{Workforce}

Recent reports show that major improvements in the workforce have taken place over the past 10 years. There are still, however, significant workforce deficits in mental health services in New Zealand (Ministry of Health, 2005a). For example, although most positions in urban districts are now filled, overall the psychiatric workforce remains depleted compared with international benchmarks. New Zealand has 288 psychiatrists (albeit 528 medical officers overall - see Table 1), including 59 child psychiatrists, representing overall
Table 1 Selected mental health and addiction occupational group workforce

\begin{tabular}{|c|c|c|c|}
\hline $\begin{array}{l}\text { Occupational } \\
\text { group }\end{array}$ & $\begin{array}{l}\text { Total } \\
\text { number }\end{array}$ & $\begin{array}{l}\text { Proportion of } \\
\text { workforce who } \\
\text { are Maori (\%) }\end{array}$ & $\begin{array}{l}\text { Proportion of } \\
\text { workforce who are } \\
\text { Pacific Islanders (\%) }\end{array}$ \\
\hline $\begin{array}{l}\text { Addiction } \\
\text { practitioners }^{\mathrm{a}}\end{array}$ & 950 & 22 & 4 \\
\hline Nurses & 3052 & 13.2 & 2.7 \\
\hline Support workers ${ }^{b}$ & 1423 & 33 & 8.2 \\
\hline $\begin{array}{l}\text { Psychiatrists and } \\
\text { other medical } \\
\text { practitioners }^{c}\end{array}$ & 528 & 3 & 0.4 \\
\hline Psychologists $^{d}$ & 1404 & 4.3 & 0.2 \\
\hline Social workers & 311 & & \\
\hline
\end{tabular}

a There are approximately 850 alcohol and drug workers and 100 problem gambling practitioners.

${ }^{b}$ This is the number of graduates of the National Certificate in Mental Health Support Work. Note that not all mental health support workers have completed the National Certificate, and not everyone who has completed it is working in mental health.

'Includes specialists (288), medical officers special scale (65), registrars (166) and 'other' (5). Although the survey recorded no Pacific doctors working in psychiatry, this table includes two Pacific practitioners because there is at least one psychiatrist and one training in psychiatry who would identify themselves as Pacific.

${ }^{d}$ Of the current surveyed registered psychologists (907), a total of 788 work in the fields of clinical psychology, rehabilitation, psychotherapy and counselling. The ethnicity percentages are from those surveyed.

Source: Ministry of Health (2005a).

ratios of approximately 1 general psychiatrist per 18000 people and 1 child and adolescent psychiatrist for 70000 people, compared with recommendations from the World Health Organization of $1 / 10000$ and $1 / 50000$, respectively (Andrews, 1991). Major deficits in the workforce remain in child and adolescent mental health services, Maori and Pacific Island clinicians and in-patient care (Table 1).

\section{Legislation}

The main pieces of legislation relating to persons with mental health disorders are the Mental Health (Assessment and Compulsory Treatment) Act 1992, the Protection of Personal and Property Rights Act 1998, the Human Rights Act 1993, the Privacy Act 1993 and the Health and Disability Commission Act 1994. Other legislation relevant to mental health includes the Criminal Procedure (Mentally Impaired Persons) Act 2003, which gives the court powers to order individuals with mental impairment who have been charged with or convicted of an imprisonable offence to accept compulsory care and rehabilitation under the Mental Health Act if mentally ill, or, in the case of people with intellectual disabilities, the Intellectual Disability (Compulsory Care and Rehabilitation) Act 2003.

The Mental Health Act seeks to protect the rights of the individual, including treatment in the 'least restrictive' circumstances, and to promote community care. It set a high threshold in terms of determining disorder by specifying that disorders must be severe and pose a serious risk to the patients themselves or others.

\section{Planning and development}

The process of deinstitutionalisation began in New Zealand in the 1970s and resulted in the closure of most of the 
psychiatric hospitals during the 1980s. It was not, however, until the 1990s that the process was comprehensively planned, implemented and realistically funded.

Three key documents from the Ministry of Health now form the National Mental Health and Addiction Strategy. These include:

O Looking Forward: Strategic Directions for Mental Health Services (1994)

O Moving Forward: The National Mental Health Plan for More and Better Services (1997)

O Te Tahuhu - Improving Mental Health 2005-2015: The Second New Zealand Mental Health and Addiction Plan (2005).

Looking Forward confirmed the strategic commitment to the shift from institution-based to community-based delivery of services, backed up by sufficient in-patient services for acute care. The two main goals of the strategy were:

o to decrease the prevalence of mental illness and mental health problems within the community

$O$ to increase the health status of (and reduce the impact of mental disorders on) consumers, their families, carers and the general community.

In 1996, a nationwide review of mental health services was undertaken by Judge Ken Mason. Recommendations from the resulting report (Ministry of Health, 1996) included a major increase in funding for mental health services, and the establishment of a three-member Mental Health Commission with a remit:

O to monitor the implementation of the National Mental Health and Addiction Strategy

O to reduce discrimination against people with mental illness

o to ensure the mental health workforce was strengthened.

Several factors have been responsible for the progress made in the development of mental health services in New Zealand. However, the Mental Health Commission's (1998) 'blueprint' for mental health services has proven to be one of the most important initiatives spurring change. The blueprint specified costed configurations of mental health services for populations of 100000 people. It aimed to deliver services, when fully implemented, to the $3 \%$ of the population most severely affected by mental illnesses, including age-related services for adults, children and youths, and the elderly. It has been augmented by a series of national strategies covering mental health promotion and prevention, workforce development, Maori, Pacific Island and Asian mental health, primary healthcare, activity and outcomes measurement. Maori mental health in particular has received attention through the development of culturally specific services run 'by Maori for Maori'.

More recently, a second Mental Health and Addictions Plan, Te Tahuhu - Improving Mental Health, has been developed by the Ministry of Health (2005b). Covering the period 2005-15 it encompasses:

O promotion and prevention

O building mental health services

o responsiveness

workforce and culture for recovery

O Maori mental health

o primary mental healthcare

$O$ addiction

funding mechanisms for recovery

o transparency and trust

o working together.

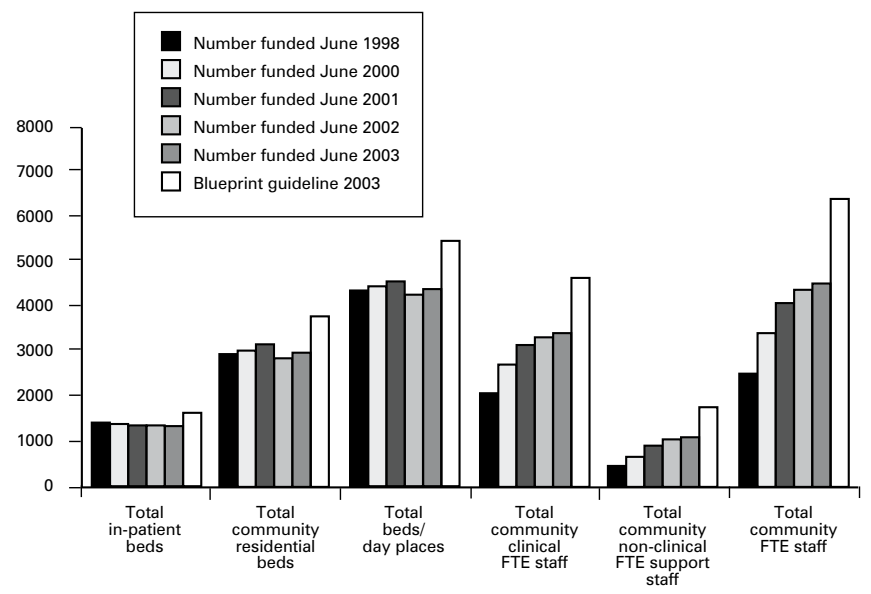

Fig. 2 Overall trends in beds and community staff funded from June 1998 to June 2003. (FTE, full-time equivalent.) Source: Mental Health Commission (2006).

\section{Progress}

Fig. 2 indicates how resource development in mental health services has increased relative to the blueprint guidelines over the period 1998-2003. Although relatively static since 1993, the configuration of in-patient and community residential beds had changed dramatically before that time, with reductions in in-patient beds and increases in community NGO beds. Since 1993, significant increases in both community clinical and non-clinical staff have taken place, in line with the blueprint. Community services now account for $69 \%$ of mental health services, whereas in the late 1980s the reverse was the case.

The Mental Health Commission (2007) has estimated that, at best, $1.9 \%$ of the population are now accessing public mental health services. This result falls below expectations the target was $3 \%$ - but needs to be seen in the context of the increasing range and quality of services. It is also anticipated that, as primary healthcare initiatives unfold, access to services for people with low-prevalence disorders and specialist services for those who are more seriously mentally ill will increase.

\section{References}

Andrews, G. (1991) The Tolkein Report: A Description of a Model Mental Health Service. University of New South Wales at St Vincent's Hospital. Mental Health Commission (1998) Blueprint for Mental Health Services in New Zealand. Mental Health Commission.

Mental Health Commission (2006) Report on Progress 2004/2005. Mental Health Commission.

Mental Health Commission (2007) Te Haererenga mo te Whakaoranga The Journey of Recovery for the New Zealand Mental Health Sector. Mental Health Commission.

Ministry of Health (1996) Inquiry Under Section 47 of the Health and Disability Services Act 1993 in Respect of Certain Mental Health Services (also known as the Mason report). Ministry of Health.

Ministry of Health (2005a) Tauawhitia te Wero - Embracing the Challenge: National Mental Health and Addiction Workforce Development Plan 2006-2009. Ministry of Health.

Ministry of Health (2005b) Te Tahuhu - Improving Mental Health 20052015. The Second New Zealand Mental Health and Addiction Plan. Ministry of Health.

Ministry of Health (2006) Te Rau Hinengaro: The New Zealand Mental Health Survey. Ministry of Health.

Ministry of Social Development (2006) The Social Report 2006. Ministry of Social Development.

Wheeler, E., Robinson, E. \& Robinson, G. (2005) Admissions to acute psychiatric inpatient services in Auckland, New Zealand: a demographic and diagnostic review. New Zealand Medical Journal, 118, U1752. 